\title{
Pemanfaatan Panas Pada Elemen Peltier Untuk Membuat Charger Handphone
}

\author{
Elyakim Nova Supriyedi Patty ${ }^{1}$, Cornelia Sri Sulasmi Padaka ${ }^{2}$, Maria Imakulata Bora ${ }^{3}$, \\ Frenly Martha Ate ${ }^{4}$, Serliana Muri Ate ${ }^{5}$, Elisabeth Kaley ${ }^{6}$, Tresia Desinta Wole ${ }^{7}$, \\ Marselina Osa Awa ${ }^{8}$, Antonius Gawi Lokku', Kanisius Bili Bulu10 \\ ${ }^{1-10}$ Program Studi Pendidikan Fisika STKIP Weetebula
}

Elyakim N. S. Patty, STKIP Weetebula; elyakim_nsp@yahoo.co.id
Abstrak: Handphone merupakan sebuah perangkat elektronik yang tidak lepas dari kehidupan manusia. Keberadaannya sangat mempermudah berbagai pekerjaan yang dilakukan oleh manusia. Untuk kestabilan pengoperasian handphone membutuhkan energy dalam bentuk baterai yang dapat digunakan untuk menghidupkan handphone. Charger handphone merupakan sarana yang dipergunakan untuk pengisian daya pada baterai. Adakalanya di daerah yang kekurangan aliran listrik (PLN), penggunaan handphone untuk akses informasi dan komunikasi menjadi terhambat. Berdasarkan kondisi ini maka dirancang sebuah alat charger sederhana yang dapat dipergunakan mencas handphone dengan memanfaatkan energy dari alam seperti panas api dan panas uap air yang dirancang dengan bantuan elemen peltier sebagai penghantar panas untuk menghasilkan tegangan. Tujuan penelitian ini adalah untuk mengetahui tegangan yang dihasilkan oleh elemen peltier pada charger yang dirancang.

Keywords: Charger handphone, elemen peltier

\section{Pendahuluan}

Perkembangan teknologi terus berjalan sangat pesat. Banyak sekali teknologi-teknologi baru dan canggih yang semakin mempermudah kegiatan sehari-hari manusia. Teknologi canggih tersebut salah satunya adalah alat telekomunikasi dalam hal ini handphone. Hampir semua orang dari kalangan bawah ke atas mempunyai handphone. Handphone digunakan karena dapat mempermudah orang untuk mendapatkan informasi dari orang lain. Handphone juga memiliki komponen penting salah satunya adalah baterai. Baterai ini berfungsi untuk menghidupkan handphone karena tanpa baterai handphone tidak bisa hidup dan tidak dapat digunakan sebagai alat bantu komunikasi. Handphone pada zaman ini sudah menjadi bagian dari kehidupan setiap orang, baik sedang tidur maupun duduk santai-santai. Manusia dijaman sekarang tidak bisa jauh dari handphone. Keberadaan handphone seakan tidak bisa di gantikan dengan alat komunikasi lainya karena sifatnya yang praktis dan dapat di bawah kemanamana. Penggunaan handphone secara terusmenerus tentu mengurangi daya pada baterai yang digunakan, sehingga perlu melakukan pengisian daya ulang dengan menggunakan alat cas atau charger handphone. Charger handphone yang biasa digunakan adalah adaptor yang dihasilkan dari sumber daya Alternating Current (AC) PLN yang ada di setiap rumah tangga dan pada bangunan lain. Melihat lebih jauh bahwa penggunaan handphone bukan saja pada saat berada di rumah atau di tempat yang menyediakan 
sumber daya AC tetapi bisa juga digunakan di tempat terpencil yang tidak ada sumber daya AC serta jika terjadi pemadaman listrik maka akan sulit mendapatkan atau mengisi kembali arus pada handphone.

Kondisi demikian membuat waktu kita semakin lama karena harus menunggu handphone yang harus diisi daya pada tempat lain yang jangkauan lokasinya cukup jauh. Krisis energy yang demikian menjadi masalah besar bagi manusia pada umumnya. Sementara kebutuhan manusia akan energy terbarukan semakin tinggi. oleh karena itu dibutuhkan sebuah teknologi untuk mengatasi krisis energy.

Energy sendiri merupakan kemampuan untuk melakukan kerja. (Hamdi, 2016) Dalam kehidupan sehari-hari energy dapat timbul dalam berbagai bentuk seperti energy surya, energy angin, energy air, energy kimia, energy nuklir, dan bentuk energy lainnya karena energy dapat berubah dari satu bentuk energy ke bentuk energy lainnya.

Dengan ilmu yang dimilikinya manusia saat ini mulai berinovasi untuk menciptakan suatu piranti yang dapat mengatasi krisis energy tersebut. Seperti saat ini sudah banyak pemanfaatan energy dari alam yang membantu handphone dapat mengisi dalam berbagai keadaan.

Maka peneliti merujuk pada media yang cocok untuk menghasilkan arus listrik yaitu dengan memanfaatkan daya panas pada elemen peltier. Dalam hal ini peltier yang dimaksudkan adalah salah satu komponen elekronik di jaman ini yang bisa menciptakan panas atau dingin pada salah satu sisinya.
(Fikri, 2016) Energy panas bisa dimanfaatkan sehingga bisa lebih berguna dengan mengkonversi atau mengubahnya menjadi energy lisrik. Modul peltier dapat digunakan untuk mengaplikasikan efek seebeck. Yaitu kondisi yang mengubah perbedaan suhu menjadi energy listrik ketika ada dua bahan yang berbeda kedua ujungnya dihubungkan satu sama lain.

Jenis peltier yang digunakan adalah TEC. Dilansir dari artikel oleh (Hadiansyah, Roza, \& Rosalina, 2018) Thermoectric Cooler (TEC) dimana didalamnya adalah komponen elektronika yang menggunakan efek peltier untuk membuat aliran panas ( heat flux) pada sambungan (junction) antara dua jenis material yang berbeda Thermoelektric cooler banyak dimanfaatkan sebagai pendingin CPU, computer, kulkas mini, AC mini, cool box serta banyak lagi peralatan yang memnafaatkan sisi dingin yang dihasilkan pada peltier. Sedangkan elemen sisi panasnya dapat dijumpai pada penggunaan pemanas air seperti dispenser dan ketel pemanas air dan lain sebagainya.

Dari latar belakang yang sudah dijelaskan maka dilakukan suatu penelitian dengan judul "Pemanfaatan Panas Pada Elemen Peltier Untuk Membuat Charger Handphone".

Tujuan dari penelitian ini adalah untuk mengetahui bagaimana penggunaan peltier dengan memanfaatkan energi panas untuk charger handphone.

\section{Metode Penelitian}


Penelitian yang dilakukan merupakan penelitian eksperimen. Adalah metode ilmiah yang digunakan untuk mencari pengaruh pada suatu perlakuan tertentu. Sedangkan menurut (Kristanto, 2018) penelitian eksperimen adalah metode penelitian kuantitatif yang digunakan untuk melihat pengaruh variable bebas terhadap variable terikat yang dapat dikendalikan.

\section{Desain Penelitian}

Pada penelitian yang dilakukan, dirancang alat charger sederhana seperti pada gambar dibawah ini:

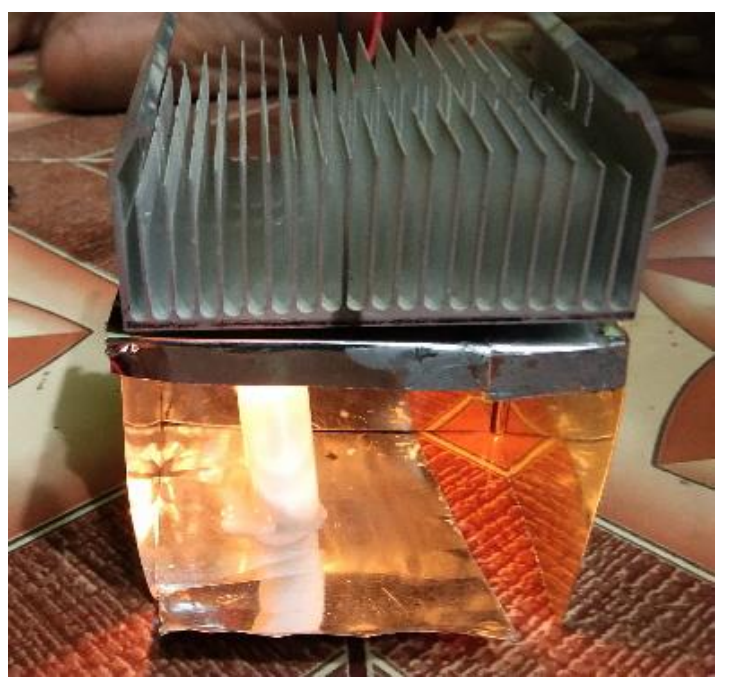

\section{Waktu dan Tempat}

Penelitian ini dilakukan selama berlangsungnya mata kuliah Laboratorium Fisika 2 pada bulan Februari-Maret atau sebelum Ujian Tengah Semester Ganjil STKIP Weetebula. Dan dalam seminggu sekali melakukan penelitian. Adapun penelitian berlangsung di kampus STKIP Weetebula.

\section{Alat dan Bahan}

\begin{tabular}{|c|c|c|}
\hline Alat & ahan & Jumlah \\
\hline Elemen & Peltier & 9 buah \\
\hline
\end{tabular}

\begin{tabular}{|c|c|}
\hline TEC1-12706 & \\
\hline Plat Seng & 1 meter \\
\hline Heatsink/Pendingin & 2 buah \\
\hline Cairan Spiritus & Secukupnya \\
\hline Lilin & 2 buah \\
\hline Korek Api & 1 buah \\
\hline Lem Paking & 2 buah \\
\hline USB Conector mobil & 1 buah \\
\hline Solder & 1 buah \\
\hline T nol & secukupnya \\
\hline Lampu pelita & 1 buah \\
\hline Multimeter & 1 \\
\hline
\end{tabular}

\section{Prinsip Kerja Alat Percobaan}

Alat percobaan yang dirancang akan bekerja dengan memanfaatkan energy panas pada nyala lilin, uap air panas, api lampu pelita, dan api pada pembakaran spiritus. Panas ini akan diterima oleh elemen peltier yang kemudian dapat mengahasilkan tegangan yang bisa digunakan untuk mengisi daya pada handphone. Dan peltier dirancang secara seri dengan menhubungkan beberapa buah peltier.

\section{Eksperimen yang Dilakukan}

Untuk menghitung tegangan yang dihasilkan oleh elemen peltier atau pengumpulan datanya menggunakan perhitungan dengan persamaan sebagai berikut:

Nilai Rata-rata Tegangan

$$
\underline{V}=\frac{V_{1}+V_{2}+V_{3}+V_{4}+\cdots+V_{n}}{n}
$$

Standar Deviasi

$$
S_{\underline{V}}=\sqrt{\frac{\sum_{i=1}^{i}\left(V_{i}-\underline{V}\right)^{2}}{k(k-1)}}
$$


Standar Deviasi Relatif

$$
S_{V r}=\frac{S_{\underline{V}}}{\underline{V}}
$$

Tegangan yang diperoleh

\section{Pembahasan}

$$
V=\underline{V} \pm S_{\underline{V}}
$$

\section{A. Pengertiaan Charger}

Berdasarkan laman (Wikipedia) Char adalah peranti yang digunakan untuk men energy ke dalam baterai dengan memasukkan a listrik melaluinya dan sering digunakan o pemakai handphone melalui energi listrik yang bersumber dari PLN. sehingga charger tersebut mempunyai kelemahan, yaitu tidak bisa digunakan di daerah yang terbatas ketersediaan sumber daya listrik..

Fungsi charger adalah merubah tegangan listrik dari sumber utama daya listrik ke alat cas sesuai yang dibutuhkan untuk mengisi baterai. Kualitas adaptor charger dapat dilihat dari output tegangannnya. Semakin mendekati 5 Volt akan semakin baik fungsinya.

\section{B. Pengertian Heatsink}

Dilansir dari laman nesabamedia oleh (Hermawan, 2019) Heatsink merupakan sebuah komponen elektronika yang digunakan pada computer maupun laptop yang mempunyai fungssi utama untuk mendinginkan komponen tertentu yang berusaha untuk dilindungi.

Heatsink merupakan alat pengendali panas pasif yang menyerap panas yang dipanaskan atau dihasilkan oleh komponen elektronik kemudian dipindahkan kemedia disekitarnya umumnya heatsink juga dilengkapi dengan kipas untuk membantu proses pendinginan. Sehingga fungsi heatsing yang paling utama adalah untuk mengendalikan atau mendinginkan temperatur atau suhu pada komponen elektronika.

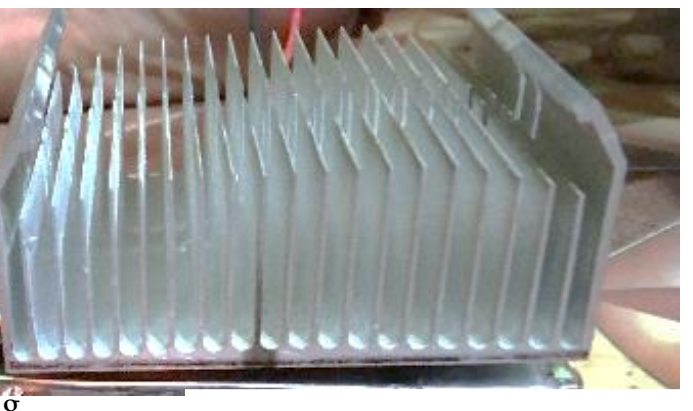

Gambar Heatsink

Pada penelitian ini heatsink digunakan untuk mengukur tegangan pada peltier sehingga jika tegangan yang dihasilkan kurang besar maka bisa untuk menghidupkan kipas yang berada pada heatsink itu sendiri sehingga Charger yang telah di pasang pun dapat melakukan pengisian daya pada Handpone.

\section{Peltier}

Peltier adalah komponen elektronika yang dapat membuat aliran panas pada sambungan antara dua jenis material yang berbeda. Komponen ini bekerja sebagai pompa panas aktif dalam bentuk padat yang memindahkan panas dari satu sisi ke sisi permukaan lainnya yang berseberangan, dengan konsumsi energi elektris tergantung pada arah aliran arus listrik. Komponen ini dikenal dengan nama peltier thermoletric cooler (TEC). TEC dapat juga digunakan sebagai pemanas dengan cara membalik komponen elektronika ini. Dengan demikian, TEC dapat digunakan sebagai alat 
pengontrol temperatur. TEC mengasbsorbsi panas melalui salah satu sisinya dan memancarkan panas melalui satu sisi lainnya. Pada bagian sisi TEC yang mengabsorbsi panas terjadi efek pendinginan, inilah yang dimanfaatkan untuk berbagai keperluan pendinginan. Efek peltier adalah efek timbulnya panas pada satu sisi dan timbulnya dingin pada sisi lainnya manakala arus listrik DC dilewatkan kepada untaian dari dua tipe material berbeda yang dipertemukan. Material tersebut adalah material thermoelectric element yang dibuat dari bahan semikonduktor.

Apabila pada kedua konduktor yang berada diujung-ujung untaian diberikan tegangan DC, maka arus listrik akan mengalir dari sumber tegangan yang berpotensial positif, melalui semikonduktor tipe $\mathrm{N}$ lalu ke semikonduktor tipe $\mathrm{P}$ hingga berakhir disumber tegangan yang berpotensial negativ. Arah aliran electron akan berkebalikan dengannya. Efeknya adalah dibagian sisi atas dimana terjadi pertemuan antara semikonduktor tipe $\mathrm{N}$ dan semikonduktor tipe $\mathrm{P}$ (melalui perantaraan logam konduktor) panas diabsorbsi sehingga dibagian sisi ini efeknya adalah timbulnya dingin. Sedangkan dibagian sisi bawah yang timbul adalah kebalikannya, yaitu panas. Perbedaan suhu diantara kedua sisi itu berkisar 40$70^{\circ} \mathrm{C}$. Prinsip ini diterapkan pada pembuatan charger HP.

TEC disusun dari untaian-untaian thermocouple yang terangkai secara seri. Kesemuanya di-packing di dalam satu wadah fisik persegi yang kompak.

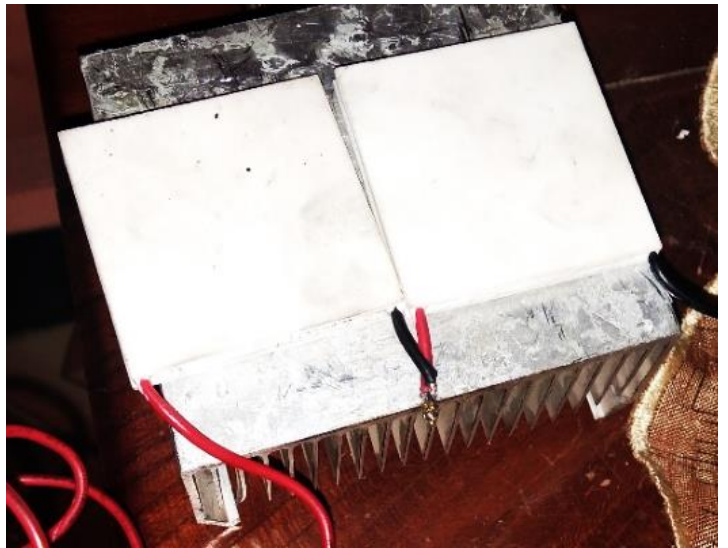

Gambar Peltier

\section{Multimeter}

Multimeter adalah alat ukur yang di pakai untuk mengukur tegangan listrik, dan tahanan (resistansi). Sedangkan pada perkembangannya multimeter masih bisa digunakan untuk beberapa fungsi seperti mengukur temperatur, induktansi, frekuensi, dan hambatan dan tegangan. Multimeter terdiri atas dua jenis yaitu multimeter digital dan analog.

\section{Analisis Data Penelitian}

Berdasarkan penelitian yang dilakukan diperoleh hasil seperti pada penjabaran data-data sebagai berikut:

\section{Data Hitung Tegangan Peltier}

Tabel 1.1

\begin{tabular}{|c|c|c|c|}
\hline $\begin{array}{c}\text { Percobaan } \\
\text { Ke- }\end{array}$ & Perlakuan & $\begin{array}{c}V \\
(\text { Volt })\end{array}$ & $\begin{array}{c}\mathbf{t} \\
(\mathbf{s})\end{array}$ \\
\hline 1 & & 0,43 & 70 \\
\hline 2 & & 0,45 & 75 \\
\hline 3 & & 0,45 & 80 \\
\hline 4 & & 0,45 & 85 \\
\hline 5 & \multirow{2}{*}{ Dipanaskan } & 0,45 & 90 \\
\hline
\end{tabular}




\begin{tabular}{|c|c|c|c|}
\hline 6 & dengan uap & 0,47 & 95 \\
\hline 7 & air mendidih & 0,47 & 100 \\
\cline { 1 - 1 } 8 & (2 buah & 0,49 & 105 \\
\cline { 1 - 1 } 9 & peltier $)$ & 0,49 & 110 \\
\hline 10 & & 0,55 & 115 \\
\hline
\end{tabular}

Nilai Rata-rata Tegangan

$$
\begin{gathered}
\underline{V}=\frac{0,43+(0,45 \times 4)+(0,47 \times 2)+(0,49 \times 2)+0,55}{10} \\
\underline{V}=\frac{0,43+1,8+0,94+0,98+0,55}{10} \\
\underline{V}=\frac{4,7}{10}=0,47 \text { Volt }
\end{gathered}
$$

\begin{tabular}{|c|c|c|c|}
\hline$\left|\boldsymbol{V}_{i}-\underline{\boldsymbol{V}}\right|$ & $\underline{V}$ & $V$ & $\left(\boldsymbol{V}_{i}-\underline{V}\right)^{2}$ \\
\hline$-0,04$ & \multirow{10}{*}{0,47} & 0,43 & 0,0016 \\
\hline$-0,02$ & & 0,45 & 0,0004 \\
\hline$-0,02$ & & 0,45 & 0,0004 \\
\hline$-0,02$ & & 0,45 & 0,0004 \\
\hline$-0,02$ & & 0,45 & 0,0004 \\
\hline 0 & & 0,47 & 0 \\
\hline 0 & & 0,47 & 0 \\
\hline 0,02 & & 0,49 & 0,0004 \\
\hline 0,02 & & 0,49 & 0,0004 \\
\hline 0,08 & & 0,55 & 0,0064 \\
\hline & \multicolumn{2}{|c|}{$\left(V_{i}-\underline{V}\right)^{2}$} & 0,0104 \\
\hline
\end{tabular}

Tabel 1.2

Standar Deviasi

$$
\begin{gathered}
S_{\underline{V}}=\sqrt{\frac{\sum_{i=1}^{i}\left(V_{i}-\underline{V}\right)^{2}}{k(k-1)}}=\sqrt{\frac{0,0104}{10(10-1)}} \\
S_{\underline{V}}=\sqrt{\frac{0,0104}{90}}=\sqrt{0.0001}=0,01
\end{gathered}
$$

Standar Deviasi Relatif

$$
S_{V r}=\frac{S_{\underline{V}}}{\underline{V}}=\frac{0,01}{0,47}=0,02
$$

Tegangan yang diperoleh

$$
\begin{gathered}
V=\underline{V} \pm S_{V} \\
V=0,47 \text { Volt } \pm 0,01 \text { Volt }
\end{gathered}
$$

$V=0,48$ Volt atau $V=0,46$ Volt

Ketelitian $=1-\frac{s_{V}}{\underline{V}} \times 100 \%$

Ketelitian $=1-\frac{0,01}{0,47} \times 100 \%=98 \%$

Grafik Hubungan Tegangan (Volt) Terhadap Waktu (sekon) untuk panas dari uap air mendidih

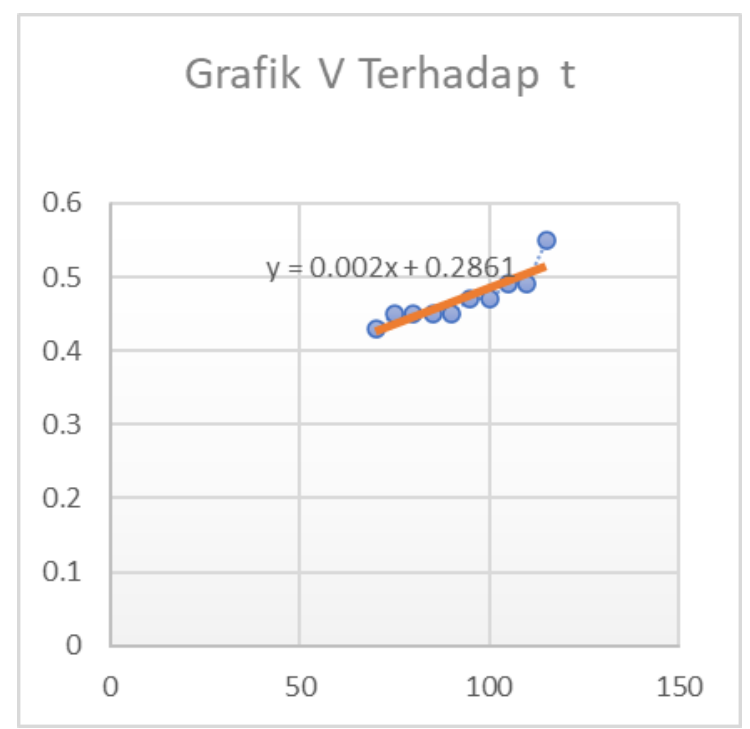

Note: Semakin lama air mendidih, uap air akan semakin panas dan tegangan peltier semakin lama semakin meningkat.

Tabel 2.1

Batas Ukur: 10 Volt

\begin{tabular}{|c|c|c|c|}
\hline $\begin{array}{c}\text { Percobaan } \\
\text { Ke- }\end{array}$ & Perlakuan & $\begin{array}{c}V \\
\text { (Volt) }\end{array}$ & $\begin{array}{c}\mathbf{t} \\
(\mathbf{s})\end{array}$ \\
\hline 1 & Dipanaskan & 2 & 60 \\
\hline 2 & dengan & 2 & 62 \\
\hline 3 & perantara & 2 & 64 \\
\cline { 1 - 1 } \cline { 1 - 1 } & kompor & 2 & 66 \\
\hline 5 & kecil dari & 2 & 68 \\
\hline 6 & seng plat & 2 & 70 \\
\hline
\end{tabular}




\begin{tabular}{|c|c|c|c|}
\hline 7 & dan lilin & 2 & 72 \\
\hline 8 & sebagai & 2 & 74 \\
\hline 9 & sumber & 2 & 76 \\
\cline { 1 - 1 } 10 & $\begin{array}{c}\text { panas (4 } \\
\text { buah peltier })\end{array}$ & 2 & 78 \\
\hline & & \\
\hline
\end{tabular}

Nilai Rata-rata Tegangan

$$
\begin{gathered}
\underline{V}=\frac{V_{1}+V_{2}+V_{3}+V_{4}+\cdots+V_{n}}{n} \\
\underline{V}=\frac{2+2+2+2+2+2+2+2+2+2}{10} \\
\underline{V}=\frac{20}{10}=2 \text { Volt }
\end{gathered}
$$

\begin{tabular}{|c|c|c|c|}
\hline$\left|\boldsymbol{V}_{\boldsymbol{i}}-\underline{\boldsymbol{V}}\right|$ & $\frac{\underline{V}}{(\text { Volt })}$ & $\begin{array}{c}\boldsymbol{V} \\
\text { (Volt) }\end{array}$ & $\left(V_{i}-\underline{V}\right)^{2}$ \\
\hline 0 & \multirow{10}{*}{2} & 2 & 0 \\
\hline 0 & & 2 & 0 \\
\hline 0 & & 2 & 0 \\
\hline 0 & & 2 & 0 \\
\hline 0 & & 2 & 0 \\
\hline 0 & & 2 & 0 \\
\hline 0 & & 2 & 0 \\
\hline 0 & & 2 & 0 \\
\hline 0 & & 2 & 0 \\
\hline 0 & & 2 & 0 \\
\hline & \multicolumn{2}{|c|}{$\left(V_{i}-\underline{V}\right)^{2}$} & 0 \\
\hline
\end{tabular}

Tabel 2.2

Standar Deviasi

$$
\begin{gathered}
S_{\underline{V}}=\sqrt{\frac{\sum_{i=1}^{i}\left(V_{i}-\underline{V}\right)^{2}}{k(k-1)}}=\sqrt{\frac{0}{10(10-1)}} \\
S_{\underline{V}}=\sqrt{0}=0
\end{gathered}
$$

Standar Deviasi Relatif

$$
S_{V r}=\frac{S_{\underline{V}}}{\underline{V}}=\frac{0}{2}=0
$$

Tegangan yang diperoleh

$$
\begin{aligned}
V=\underline{V} \pm S_{\underline{V}} \\
V=2 \text { Volt } \pm 0 \text { Volt } \\
V=2 \text { Volt }
\end{aligned}
$$

Ketelitian $=1-\frac{s_{V}}{\underline{V}} \times 100 \%$

Ketelitian $=1-0 \times 100 \%=100 \%$

Grafik Hubungan Tegangan(Volt) Terhadap Waktu (sekon) untuk panas dari api pada lilin

\section{Grafik V terhadap t}

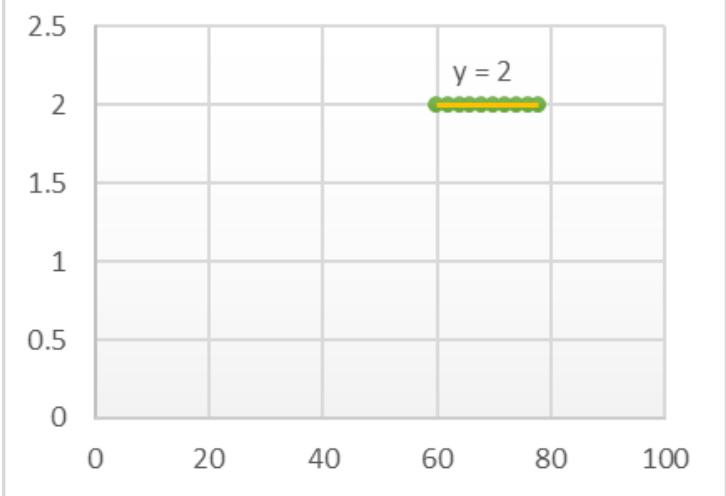

Note: Saat lilin dinyalakan maka seng plat akan panas. Karena nyala lilin yang stabil penyebaran panaspun merata dan tegangan peltier yang dihasilkan juga stabil.

Tabel 3.1

Batas Ukur: 10 Volt

\begin{tabular}{|c|c|c|c|}
\hline $\begin{array}{c}\text { Percobaan } \\
\text { Ke- }\end{array}$ & Perlakuan & $\begin{array}{c}V \\
(\text { Volt })\end{array}$ & $\begin{array}{c}\mathbf{t} \\
(\mathbf{s})\end{array}$ \\
\hline 1 & Dipanaskan & 2 & 45 \\
\hline 2 & dengan & 2 & 50 \\
\hline 3 & perantara & 2 & 55 \\
\hline 4 & kompor & 2 & 60 \\
\hline 5 & kecil dari & 2 & 65 \\
\hline 6 & seng plat & 2,2 & 70 \\
\hline 7 & dan lampu & 2,2 & 75 \\
\hline
\end{tabular}




\begin{tabular}{|c|c|c|c|}
\hline 8 & pelita & 2,2 & 80 \\
\hline 9 & sebagai & 2,2 & 85 \\
\hline 10 & sumber & 2,2 & 90 \\
& panas (4 & & \\
& buah peltier) & & \\
\hline
\end{tabular}

Nilai Rata-rata Tegangan

$$
\begin{gathered}
\underline{V}=\frac{V_{1}+V_{2}+V_{3}+V_{4}+\cdots+V_{n}}{n} \\
\underline{2+2+2+2+2+2,2+2,2+2,2+2,2+2,2} \\
10 \\
\underline{V}=\frac{21}{10}=2,1 \text { Volt }
\end{gathered}
$$

\begin{tabular}{|c|c|c|c|}
\hline $\mid \underset{\text { Volt }}{\left|\boldsymbol{V}_{\tilde{i}}-\underline{\boldsymbol{V}}\right|}$ & $\frac{\boldsymbol{V}}{\text { (Volt) }}$ & $\begin{array}{c}\boldsymbol{V} \\
\text { (Volt) }\end{array}$ & $\left(V_{i}-\underline{V}\right)^{2}$ \\
\hline$-0,1$ & \multirow{10}{*}{2,1} & 2 & 0,01 \\
\hline$-0,1$ & & 2 & 0,01 \\
\hline$-0,1$ & & 2 & 0,01 \\
\hline$-0,1$ & & 2 & 0,01 \\
\hline$-0,1$ & & 2 & 0,01 \\
\hline 0,1 & & 2,2 & 0,01 \\
\hline 0,1 & & 2,2 & 0,01 \\
\hline 0,1 & & 2,2 & 0,01 \\
\hline 0,1 & & 2,2 & 0,01 \\
\hline 0,1 & & 2,2 & 0,01 \\
\hline & \multicolumn{2}{|c|}{$\left(V_{i}-\underline{V}\right)^{2}$} & 0,1 \\
\hline
\end{tabular}

Tabel 3.2

Standar Deviasi

$$
\begin{gathered}
S_{\underline{V}}=\sqrt{\frac{\sum_{i=1}^{i}\left(V_{i}-\underline{V}\right)^{2}}{k(k-1)}}=\sqrt{\frac{0,1}{10(10-1)}} \\
S_{\underline{V}}=\sqrt{\frac{0,1}{90}}=\sqrt{0.001}=0,03
\end{gathered}
$$

Standar Deviasi Relatif

$$
S_{V r}=\frac{S_{\underline{V}}}{\underline{V}}=\frac{0,03}{2,1}=0,0014
$$

Tegangan yang diperoleh

$$
\begin{gathered}
V=\underline{V} \pm S_{V} \\
V=2,1 \text { Volt } \pm 0,03 \text { Volt }
\end{gathered}
$$$$
V=2,13 \text { Volt atau } V=2,07 \text { Volt }
$$

Ketelitian $=1-\frac{s_{V}}{\underline{V}} \times 100 \%$

Ketelitian $=1-\frac{0,03}{2,1} \times 100 \%=99,86 \%$

Grafik Hubungan Tegangan(Volt) Terhadap Waktu (sekon) untuk panas dari api pada lampu pelita

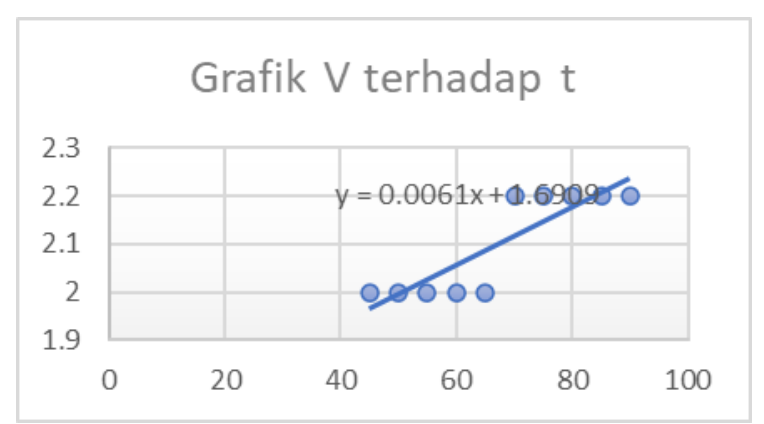

Note: Semakin lama lampu pelita dinyalakan maka seng plat akan semakin panas dan tegangan peltier semakin lama semakin meningkat. Karena nyala dari api lampu pelita cukup stabil maka tegangan yang dihasilkan mengalami peningkatan yang teratur.

Tabel 4.1

Batas Ukur: 10 Volt

\begin{tabular}{|c|c|c|c|}
\hline $\begin{array}{c}\text { Percobaan } \\
\text { Ke- }\end{array}$ & Perlakuan & $\begin{array}{c}V \\
(\text { Volt) }\end{array}$ & $\begin{array}{c}\mathbf{t} \\
(\mathbf{s})\end{array}$ \\
\hline 1 & Dipanaskan & 3 & 40 \\
\hline 2 & dengan & 3 & 45 \\
\hline 3 & perantara & 3 & 50 \\
\hline 4 & kompor & 3 & 55 \\
\hline 5 & kecil dari & 3 & 60 \\
\hline
\end{tabular}




\begin{tabular}{|c|c|c|c|}
\hline 6 & seng plat & 3 & 65 \\
\hline 7 & dan cairan & 3 & 70 \\
\hline 8 & spiritus (4 & 3,2 & 75 \\
\hline 9 & buah peltier) & 3,2 & 80 \\
\hline 10 & sebagai & 3,2 & 85 \\
\hline & sumber & & \\
& panas & & \\
& & & \\
\hline
\end{tabular}

Nilai Rata-rata Tegangan

$$
\begin{gathered}
\underline{V}=\frac{V_{1}+V_{2}+V_{3}+V_{4}+\cdots+V_{n}}{n} \\
\underline{V}=\frac{\frac{3+3+3+3+3+3+3+3 s^{2}+3,2+3,2}{10}}{\underline{V}=\frac{30,6}{10}=3,06 \text { Volt }}
\end{gathered}
$$

\begin{tabular}{|c|c|c|c|}
\hline$\left|\boldsymbol{V}_{i}-\underline{\boldsymbol{V}}\right|$ & $\frac{\underline{V}}{(\text { Volt })}$ & $\begin{array}{c}\boldsymbol{V} \\
\text { (Volt) }\end{array}$ & $\left(V_{i}-\underline{V}\right)^{2}$ \\
\hline$-0,06$ & 3,06 & 3 & 0,0036 \\
\hline$-0,06$ & & 3 & 0,0036 \\
\hline$-0,06$ & & 3 & 0,0036 \\
\hline$-0,06$ & & 3 & 0,0036 \\
\hline$-0,06$ & & 3 & 0,0036 \\
\hline$-0,06$ & & 3 & 0,0036 \\
\hline$-0,06$ & & 3 & 0,0036 \\
\hline 0,14 & & 3,2 & 0,0196 \\
\hline 0,14 & & 3,2 & 0,0196 \\
\hline 0,14 & & 3,2 & 0,0196 \\
\hline & $(V$ & & 0,084 \\
\hline
\end{tabular}

Tabel 4.2

Standar Deviasi

$$
\begin{gathered}
S_{\underline{V}}=\sqrt{\frac{\sum_{i=1}^{i}\left(V_{i}-\underline{V}\right)^{2}}{k(k-1)}}=\sqrt{\frac{0,084}{10(10-1)}} \\
S_{\underline{V}}=\sqrt{\frac{0,084}{90}}=\sqrt{0.00093}=0,03049
\end{gathered}
$$

Standar Deviasi Relatif

$$
S_{V r}=\frac{S_{\underline{V}}}{\underline{V}}=\frac{0,03049}{3,06}=0,0099
$$

Tegangan yang diperoleh

$$
\begin{gathered}
V=\underline{V} \pm S_{\underline{V}} \\
V=3,06 \text { Volt } \pm 0,03049 \text { Volt } \\
V=3,09 \text { Volt atau } V=3,029 \text { Volt } \\
\text { Ketelitian }=1-\frac{s_{V}}{\underline{V}} \times 100 \% \\
\text { Ketelitian }=1-\frac{0,03049}{3,06} \times 100 \%=99 \%
\end{gathered}
$$

Grafik Hubungan Tegangan(Volt) Terhadap Waktu (sekon) untuk panas dari api pada cairan spiritus

\section{Grafik V terhadap t}

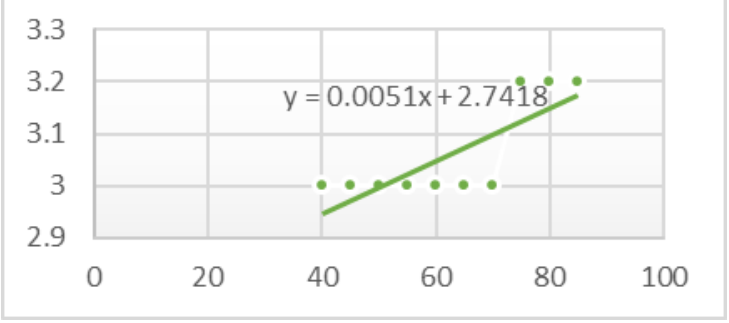

Note: Saat cairan spiritus dinyalakan maka seng plat akan panas dan tegangan peltier semakin lama semakin meningkat. Karena nyala dari api cairan spiritus cukup stabil dan merata maka tegangan yang dihasilkan mengalami peningkatan yang teratur.

\section{Kesimpulan}

Dari percobaan yang dilakukan, diperoleh hasil bahwa tegangan peltier yang dihasilkan oleh elemen panas peltier belum 
memenuhi tegangan yang dibutuhkan untuk proses charger handphone. Atau tegangan yang dihasilkan masih sangat kecil (kurang dari 5 volt). Hal ini bisa dipengaruhi oleh kualitas peltier yang digunakan tidak sesuai dengan spesifikasi tegangan produk yang terlampir saat pembelian, ataupun karena panas berlebih saat penggunaan peltier pada alat charger sederhana yang telah dirancang dan kondisi peltier yang dalam keadaan tidak optimal untuk digunakan (ada beberapa peltier mengalami kerusakan). Namun, peltier tetap dapat dipergunakan sebagai salah satu komponen utama pembuatan alat cas.

\section{Saran}

Penelitian yang dilakukan ini merupakan tahapan yang dapat dilakukan oleh peneliti untuk mengetahui keberfungsian elemen panas pada peltier. Adapun meski dalam hasil akhirnya alat charger yang dirancang belum memenuhi kriteria sebuah alat cas, maka peneliti menyarankan agar hasil penelitian ini dapat digunakan sebagai rujukan eksperimen selanjutnya yang berkaitan dengan pemanfaatan elemen panas pada peltier sebagai alat charger handphone yang mudah dirancang, mudah digunakan dan ekonomis (hemat energy).

\section{Daftar Pustaka}

Fikri, H. A. (2016). EFEKTIFITAS MODUL PELTIER TEC-12706 SEBAGAI GENERATOR DENGAN MEMANFAATKAN ENERGI PANAS DARI MODUL PELTIER TEC-12706.
Hadiansyah, H., Roza, E., \& Rosalina. (2018). Perancang Pembangkit Listrik Tenaga Panas pada Knalpot Motor. SEMINAR NASIONAL TEKNOKA Volume.3, E-70 - E-78.

Hamdi. (2016). ENERGI TERBARUKAN. Jakarta: KENCANA.

Hermawan. (2019, September). NESABAMEDIA. Retrieved from NESABAMEDIA:

www.nesabamedia.com/pengertian-

heatsink-dan-fungsi-heatsink/

Kristanto, V. H. (2018). METODOLOGI PENELITIAN PEDOMAN PENULISAN KARYA TULIS ILMIAH (KTI). Yogyakarta: PENERBIT DEEPUBLISH.

Wikipedia. (n.d.). WIKIPEDIA. Retrieved from Pengisi Baterai: https://id.m.wikipedia.org/wiki/Pengisi _baterai 